\title{
Erratum to: A methodological proposal to link Design with Additive Manufacturing to environmental considerations in the Early Design Stages
}

\author{
Foteini Markou $^{1} \cdot$ Frédéric Segonds $^{1} \cdot \operatorname{Maud~Rio}^{2} \cdot$ Nicolas Perry $^{3}$ D
}

Published online: 14 July 2017

(C) Springer-Verlag France SAS 2017

\section{Erratum to: Int J Interact Des Manuf}

\section{DOI 10.1007/s12008-017-0412-1}

Unfortunately, the given name and family names were swapped in the original online publication of this article. The correct given name and family names are given below. The original article was corrected.

Foteini Markou, Frédéric Segonds, Maud Rio, Nicolas Perry

The online version of the original article can be found under doi:10.1007/s12008-017-0412-1.

Nicolas Perry

n.perry@i2m.u-bordeaux1.fr

1 Arts et Métiers ParisTech, LCPI, 151 boulevard de l'Hôpital, 75013 Paris, France

2 Univ. Grenoble Alpes, CNRS, G-SCOP, 38000 Grenoble, France

3 Arts et Métiers ParisTech, I2M, UMR 5295, 33405 Talence, France 